\title{
Evaluation of Quality Protein Maize (Zea mays L.) Hybrids for Quantitative and Quality Traits
}

\author{
Jay Prakash ${ }^{1}$, S. Lata ${ }^{2}$, Ankita Sharma ${ }^{2}$, R.D. Vekariya ${ }^{1}$, J.K. Sharma ${ }^{2}$ and Ankita Sood ${ }^{3}$ \\ ${ }^{1}$ Department of Genetics and Plant Breeding, Navsari Agricultural University, \\ Navsari, Gujarat, 396450, India \\ ${ }^{2}$ CSK Himachal Pradesh Agricultural University, Palampur, HP, 176062, India \\ ${ }^{3}$ Punjab Agricultural University, Ludhiana, Punjab, 141004, India \\ *Corresponding author
}

\begin{tabular}{|c|c|}
\hline & A B S T R A C T \\
\hline $\begin{array}{l}\text { Genetic advance, } \\
\text { Heritability, } \\
\text { Hybrids, Quality } \\
\text { protein maize, } \\
\text { Zea mays L. }\end{array}$ & \multirow{3}{*}{$\begin{array}{l}\text { Present investigation was undertaken to evaluate the single cross QPM hybrids for } \\
\text { quantitative and quality traits. The results indicated that the hybrids showed significant } \\
\text { variability for most of the traits studied. Among the } \mathrm{F}_{1} \text { hybrids SC- } 8 \text { yielded the highest } \\
\text { grain yield per plant }(170.77 \mathrm{~g}) \text { followed by SC-30 }(170.41 \mathrm{~g}) \text {, SC- } 24 \text { ( } 168.69 \mathrm{~g}) \text { and SC- } \\
20(161.96 \mathrm{~g}) \text {. Two } \mathrm{F}_{1} \text { hybrids (SC-13 and SC-19) had high tryptophan content among all } \\
\text { the hybrids. The estimate of broad sense heritability was the highest for grain yield per } \\
\text { plant }(96.70 \%) \text { followed by plant height }(96.00 \%) \text {, tryptophan content ( } 93.90 \%) \text {, days to } \\
50 \text { per cent pollen shed }(89.70 \%) \text {, protein content }(89.70 \%) \text {, days } 50 \text { per cent silking } \\
(84.50 \%), 75 \text { per cent maturity }(84.50 \%) \text {, cob placement height }(88.10 \%) \text { and grains per } \\
\text { row }(82.10 \%) \text {. The estimated genetic advance as a per cent of mean was recorded the high } \\
\text { for grain yield per plant }(61.01 \%) \text {. Thus, these traits are predominantly under the control of } \\
\text { additive gene action and hence these characters can be improved by selection. }\end{array}$} \\
\hline Article Info & \\
\hline $\begin{array}{l}\text { Accepted: } \\
\text { 15 March } 2017 \\
\text { Available Online: } \\
10 \text { April } 2017\end{array}$ & \\
\hline
\end{tabular}

\section{Introduction}

Maize (Zea mays L.) is one of the worlds' most important cereal crops for both human nutrition and livestock feed, in a number of developed and developing countries, worldwide (Prasanna et al., 2001). It is one of the most versatile promising crops having wider adaptability under wide-ranging agroclimatic conditions. In view of the changing farming scenario in the country, maize has been promising as one of the potential crops that address numerous concerns like food and nutritional security, climate change, water scarcity, bio-fuel etc (Singh et al., 2012).
Globally, maize is cultivated in $181.44 \mathrm{mha}$ with a global production of $990.64 \mathrm{mt}$ and productivity $54.60 \mathrm{q} / \mathrm{ha}$. India produced 24.35 mt of maize from 9.42 mha with productivity of $25.83 \mathrm{q} / \mathrm{ha}$ (Anonymous, 2015a,b). The maize grain accounts for about 15 to $56 \%$ of the total daily calories in the diets of people in about 25 different developing countries. Nearly $25 \%$ of maize produce in India is used for human food (Prasanna et al., 2001).

Conventional maize has two drawbacks; it lacks two amino acids viz, lysine and tryptophan (Osborne and Mendel, 1914), 
which results in poor net protein utilization and its low biological value causing wet malnutrition that leads to 'Kwashiorkor' caused by a lack of protein in the diet (Upadhyay et al., 2009). Globally, an estimated 805.3 million people were chronically undernourished in 2012-14, with insufficient food for a healthy and active life (Anonymous, 2014). India remains home to the largest numbers of undernourished people in the world; 217 million as of 2012 (Anonymous, 2012). The challenge is to deliver nutritious, safe and affordable food to an ever increasing population in the coming decades to eliminate food and nutritional insecurity.

QPM, by virtue of $30 \%$ more lysine, $55 \%$ more tryptophan, $38 \%$ less leucine and enhanced protein quality over normal maize, holds immense promise for alleviating protein malnutrition. The biological value of QPM is $80 \%$ as compared to $45 \%$ of conventional maize. In opaque 2 maize proteins, nitrogen balance index is close to those of skimmed milk (0.72 and 0.80, respectively) (Prasanna et al., 2001). opaque 2 maize offers $90 \%$ of the nutritional value of skim milk (Upadhyay et al., 2009), the standard for adequate nutrition value which has been demonstrated for young children (FAO 1992). In order to meet the nutritional requirement among resource poor people globally. It is important to develop and deploy improved, low-cost, affordable QPM hybrids, with higher grain yield and quality to provide a better food and nutrition security of maize-based population.

The efficiency with which genotypic variability can be exploited by selection depends upon heritability and the genetic advance of traits (Bilgin et al., 2010). Cognizance of heritability would be most useful to improve the trait, to predict gain from selection and to determine the relative importance of genetic effects. In designing an effective breeding program in QPM hybrid development the knowledge of genetic parameters like heritability and genetic advance is of utmost importance. In view of this, the study was undertaken to estimate the mean, range, heritability and genetic advance among different quantitative and quality traits in QPM single cross $F_{1}$ hybrids so that these information may be utilized in the development of high yielding QPM hybrids for North Western Himalayan regions.

\section{Materials and Methods}

The experiment comprising 42 single cross $F_{1}$ hybrids along with two single cross QPM checks viz., HQPM 1 and Vivek QPM 9 and non-QPM check EHL161708. These $F_{1}$ hybrids along with checks were evaluated in $\alpha$-RBD design with plot size of $3.0 \times 1.2 \mathrm{~m}^{2}$ and row to row and plant to plant distance of $60 \mathrm{~cm}$ and $20 \mathrm{~cm}$, respectively with 2 replications, 15 blocks/replication and 3 entries/block (having 2 rows/plot) following standard agronomic practices at Experimental Farm, Department of Crop Improvement, Chaudhary Sarwan Kumar Himachal Pradesh Krishi Vishvavidyalaya, Palampur, Himachal Pradesh. The data on morphometric traits viz., days to $50 \%$ pollen shed, days to $50 \%$ silking, days to $75 \%$ maturity and grain yield, were recorded on plot basis whereas, plant height, cob placement height, 100-seed weight, cob length, cob girth, kernel rows per ear and grains per row from 10 individual plants per hybrid and were averaged; while qualitatively measured traits were protein content and tryptophan content. The crude protein content for each entry was calculated by Micro-Kjeldhal Method (AOAC, 1965) and tryptophan content was estimated by method given by Mertz et al., (1975). Morphological traits were measured based on maize descriptors developed by the Bioversity International. 


\section{Results and Discussion}

A perusal study on mean performance revealed wide range of variation for all the traits in the study on different scales (Table 1). The results were interpreted with best check for individual trait. The range observed for days to anthesis was 51.00-65.50 days with overall mean of 59.21 days. The tested $\mathrm{F}_{1}$ hybrids SC-9, SC-36 and SC-37 were the earliest to tassel. Days to silking varied from 53.00-66.50 with overall mean of 60.91 days. The tested $\mathrm{F}_{1}$ hybrids SC-7 was the earliest to silk. The $\mathrm{F}_{1}$ hybrids took $92.50-105.50$ with overall mean 101.87 days to maturity. None of the $F_{1}$ hybrids was found superior to the best check Vivek QPM 9 for maturity traits but many of the hybrids found superior to the non QPM check EHL161708 (Tested $F_{1}$ hybrids were derived from opaque2 introgressed inbred lines of EHL161708). Results are in congruence with the findings of Lal and Dhirendra (2014) who reported significant difference among quality protein maize; this indicates the existence of sufficient variation in the material studied. The mean plant and cob placement heights of the $\mathrm{F}_{1}$ hybrids ranged from $133.50-211.00 \mathrm{~cm}$ and respectively. The $\mathrm{F}_{1}$ hybrid SC-23 exhibited lowest plant height and cob placement height $(133.50 \mathrm{~cm}$ and $65.30 \mathrm{~cm}$, respectively).

The $\mathrm{F}_{1}$ hybrid $\mathrm{SC}-8 \quad(170.66 \mathrm{~g})$ yielded highest grain yield per plant followed by SC30 (170.41 g), SC-24 (168.69 g), SC-20 (161.96 g), SC-36 (148.78 g), SC-22 (146.54 g), SC-21(137.49 g) and SC-27 (136.27 g). 100 -seed weight of tested $\mathrm{F}_{1}$ hybrids ranged from 18.54-34.06 $\mathrm{g}$ (SC-12 and SC-20 respectively) with mean $28.75 \mathrm{~g}$. Cob length ranges from 9.63 to 17.38 with an average $14.37 \mathrm{~cm}$. The maximum cob length was obtained from SC-7 followed by SC-19 and SC-27. Cob girth ranges from 10.57 to 14.31 with a mean value of $12.67 \mathrm{~cm}$. The maximum cob girth was obtained from SC-20 followed by SC-4. Kernel row per ear of $\mathrm{F}_{1}$ hybrids ranges from 12.40-16.40 with an average 13.72. Grains per row ranged from 17.9036.60 with an average 29.32 .

Among quality traits protein content in $\mathrm{F}_{1}$ hybrids ranges from 7.10-10.94 with an average 8.54. The tested $\mathrm{F}_{1}$ hybrid SC-4 $(10.94 \%)$ exhibited maximum protein content followed by SC-13 (10.91\%), SC-27 (10.79\%), SC-24 and SC-32 (10.15\%), SC-7 (10.06\%), SC-10 (10.05\%), SC-17 (9.82\%), SC-18 (9.68\%), SC-21 (9.42\%). Tryptophan content ranged from $0.41-0.87$ with a mean value of 0.77 . The tested $\mathrm{F}_{1}$ hybrid SC-13 $(0.87 \%)$ expressed high tryptophan content followed by SC-19 (0.86\%). However, $\mathrm{F}_{1}$ hybrid SC-13 showed high protein and tryptophan content.

The extent of variability measured in terms of mean, range, heritability in broad sense, genetics advance and genetic advance as per cent of means were presented in table 2 . The mean values of the traits and ranges showed sufficient amounts of variation for morphological and biochemical components of QPM $F_{1}$ hybrids.

The estimate of heritability is of tremendous significance to the breeders as its magnitude indicates the reliability with which a genotype can be deciphered by its phenotypic expression (Lush, 1940). Most of the traits had high heritability estimates indicating the preponderance of additive gene action. The estimate of broad sense heritability was the highest for grain yield per plant $(96.70 \%)$, plant height $(96.00 \%)$, tryptophan content $(93.90 \%)$, days to $50 \%$ pollen shed $(89.70 \%)$, protein content $(89.70 \%)$, cob placement height $(88.10 \%)$, silking $(84.50 \%), 75 \%$ maturity $(84.50 \%)$ and grains per row $(82.10 \%)$. 
Int.J.Curr.Microbiol.App.Sci (2017) 6(4): 1851-1859

Table.1 Mean performance of QPM $F_{1}$ hybrids for different characters

\begin{tabular}{|c|c|c|c|c|c|c|c|c|c|c|c|c|c|c|}
\hline $\begin{array}{l}\text { Sr. } \\
\text { No. }\end{array}$ & $F_{1} s^{\prime}$ & $\begin{array}{c}\text { Days } \\
\text { to } 50 \% \\
\text { pollen } \\
\text { shed }\end{array}$ & $\begin{array}{c}\text { Days } \\
\text { to } \\
50 \% \\
\text { silking }\end{array}$ & $\begin{array}{c}\text { Days to } \\
75 \% \\
\text { maturity }\end{array}$ & $\begin{array}{l}\text { Plant } \\
\text { height } \\
(\mathrm{cm})\end{array}$ & $\begin{array}{c}\text { Cob } \\
\text { placement } \\
\text { height } \\
(\mathrm{cm})\end{array}$ & $\begin{array}{c}\text { Grain } \\
\text { yield/plant } \\
(\mathrm{g})\end{array}$ & $\begin{array}{c}100- \\
\text { seed } \\
\text { weight } \\
(\mathrm{g})\end{array}$ & $\begin{array}{l}\text { Cob } \\
\text { length } \\
(\mathrm{cm})\end{array}$ & $\begin{array}{l}\text { Cob } \\
\text { girth } \\
(\mathrm{cm})\end{array}$ & $\begin{array}{c}\text { Kernel } \\
\text { rows/ear }\end{array}$ & Grains/row & $\begin{array}{c}\text { Protein } \\
\text { content } \\
(\%)\end{array}$ & $\begin{array}{l}\text { Tryptophan } \\
\text { content }(\%)\end{array}$ \\
\hline 1 & SC-1 & 61.00 & 62.50 & 100.50 & 139.20 & 78.50 & 78.31 & 25.21 & 13.93 & 11.87 & 13.50 & 24.70 & 7.10 & 0.76 \\
\hline 2 & $\mathrm{SC}-2$ & 59.00 & 61.00 & 103.50 & 179.50 & 92.80 & 121.95 & 29.56 & 13.82 & 12.70 & 13.70 & 32.40 & 8.63 & 0.79 \\
\hline 3 & SC-3 & 60.00 & 61.00 & 104.50 & 161.10 & 90.50 & 105.89 & 30.21 & 14.40 & 13.07 & 13.80 & 28.70 & 9.17 & 0.75 \\
\hline 4 & SC-4 & 58.00 & 60.00 & 102.50 & 157.50 & 87.90 & 115.17 & 30.28 & 15.07 & 14.22 & 14.20 & 31.80 & 10.94 & 0.68 \\
\hline 5 & $\mathrm{SC}-5$ & 58.00 & 59.50 & 99.00 & 186.70 & 101.00 & 106.76 & 32.17 & 15.35 & 14.10 & 14.00 & 31.30 & 8.63 & 0.72 \\
\hline 6 & SC-6 & 58.00 & 59.00 & 102.50 & 191.80 & 104.80 & 130.42 & 33.32 & 14.84 & 13.63 & 13.60 & 32.00 & 8.80 & 0.73 \\
\hline 7 & SC-7 & 57.00 & 58.50 & 101.00 & 190.70 & 106.50 & 132.57 & 31.74 & 17.38 & 13.85 & 13.20 & 36.60 & 10.07 & 0.83 \\
\hline 8 & SC-8 & 57.50 & 59.50 & 103.50 & 169.20 & 92.05 & 170.66 & 31.20 & 14.83 & 13.43 & 14.00 & 31.60 & 8.65 & 0.81 \\
\hline 9 & SC-9 & 56.50 & 59.00 & 104.00 & 157.10 & 96.00 & 122.91 & 33.16 & 15.43 & 13.26 & 14.00 & 35.10 & 9.32 & 0.77 \\
\hline 10 & SC-10 & 57.50 & 60.00 & 104.50 & 199.80 & 118.00 & 105.56 & 33.04 & 14.78 & 13.42 & 13.40 & 28.30 & 10.05 & 0.80 \\
\hline 11 & SC-11 & 62.00 & 63.00 & 100.50 & 146.80 & 88.80 & 66.25 & 24.81 & 13.41 & 11.39 & 13.80 & 23.90 & 7.74 & 0.79 \\
\hline 12 & SC-12 & 65.00 & 66.50 & 103.50 & 141.20 & 78.50 & 52.69 & 18.54 & 11.97 & 10.57 & 13.80 & 22.80 & 7.88 & 0.83 \\
\hline 13 & SC-13 & 59.00 & 60.00 & 99.50 & 192.80 & 106.10 & 123.80 & 29.66 & 15.77 & 12.73 & 13.60 & 31.50 & 10.91 & 0.87 \\
\hline 14 & SC-14 & 60.00 & 61.50 & 99.00 & 198.50 & 120.00 & 131.21 & 29.56 & 14.07 & 12.29 & 14.20 & 29.70 & 9.19 & 0.82 \\
\hline 15 & SC-15 & 58.00 & 60.00 & 101.50 & 183.70 & 99.00 & 127.48 & 29.46 & 15.56 & 13.40 & 13.60 & 32.80 & 7.25 & 0.79 \\
\hline 16 & SC-16 & 61.00 & 62.00 & 103.50 & 211.00 & 118.50 & 117.42 & 29.50 & 14.52 & 11.89 & 13.20 & 32.50 & 7.59 & 0.80 \\
\hline 17 & SC-17 & 65.50 & 66.50 & 105.50 & 150.60 & 81.60 & 79.81 & 25.13 & 12.82 & 11.14 & 13.40 & 23.30 & 9.82 & 0.82 \\
\hline 18 & SC-18 & 61.50 & 63.00 & 100.50 & 148.30 & 86.50 & 67.92 & 21.52 & 14.07 & 11.57 & 13.20 & 25.70 & 9.69 & 0.83 \\
\hline 19 & SC-19 & 58.50 & 60.00 & 104.50 & 189.20 & 109.50 & 131.92 & 31.17 & 16.18 & 12.49 & 13.20 & 34.50 & 7.54 & 0.86 \\
\hline 20 & SC-20 & 58.50 & 60.00 & 100.50 & 180.00 & 113.90 & 161.96 & 34.06 & 16.01 & 14.31 & 14.20 & 34.80 & 9.12 & 0.79 \\
\hline 21 & SC-21 & 58.00 & 59.50 & 99.50 & 161.20 & 97.60 & 137.49 & 31.21 & 14.94 & 13.00 & 13.80 & 30.60 & 9.42 & 0.76 \\
\hline 22 & SC-22 & 59.00 & 60.00 & 101.00 & 191.60 & 110.00 & 146.54 & 32.45 & 15.77 & 13.74 & 14.20 & 31.00 & 7.89 & 0.79 \\
\hline 23 & SC-23 & 64.50 & 65.50 & 101.50 & 133.50 & 65.30 & 49.63 & 25.53 & 14.82 & 11.53 & 12.40 & 25.00 & 8.53 & 0.82 \\
\hline 24 & SC-24 & 58.50 & 60.00 & 100.50 & 175.50 & 88.50 & 168.69 & 29.21 & 15.53 & 12.55 & 13.20 & 30.40 & 10.15 & 0.85 \\
\hline 25 & SC-25 & 63.00 & 64.50 & 98.50 & 143.30 & 85.00 & 87.34 & 23.59 & 14.58 & 11.96 & 13.40 & 25.70 & 7.59 & 0.84 \\
\hline
\end{tabular}


Int.J.Curr.Microbiol.App.Sci (2017) 6(4): 1851-1859

\begin{tabular}{|c|c|c|c|c|c|c|c|c|c|c|c|c|c|c|}
\hline $\begin{array}{l}\text { Sr. } \\
\text { No. }\end{array}$ & $\mathrm{F}_{1} \mathrm{~s}^{\prime}$ & $\begin{array}{l}\text { Days } \\
\text { o } 50 \% \\
\text { pollen } \\
\text { shed }\end{array}$ & $\begin{array}{c}\text { Days } \\
\text { to } \\
50 \% \\
\text { silking }\end{array}$ & $\begin{array}{c}\text { Days to } \\
75 \% \\
\text { maturity }\end{array}$ & $\begin{array}{l}\text { Plant } \\
\text { height } \\
(\mathrm{cm})\end{array}$ & $\begin{array}{l}\text { Cob } \\
\text { placement } \\
\text { height } \\
(\mathrm{cm})\end{array}$ & $\begin{array}{c}\text { Grain } \\
\text { yield/plant } \\
\text { (g) }\end{array}$ & $\begin{array}{l}100- \\
\text { seed } \\
\text { weight } \\
(\mathrm{g})\end{array}$ & $\begin{array}{l}\text { Cob } \\
\text { length } \\
(\mathrm{cm})\end{array}$ & $\begin{array}{l}\text { Cob } \\
\text { girth } \\
(\mathrm{cm})\end{array}$ & $\begin{array}{c}\text { Kernel } \\
\text { rows/ear }\end{array}$ & Grains/row & $\begin{array}{c}\text { Protein } \\
\text { content } \\
(\%)\end{array}$ & $\begin{array}{l}\text { Tryptophan } \\
\text { content }(\%)\end{array}$ \\
\hline 26 & SC-26 & 59.00 & 60.50 & 99.00 & 172.00 & 91.90 & 110.02 & 29.43 & 14.71 & 12.87 & 13.80 & 32.40 & 9.37 & 0.71 \\
\hline 27 & SC-27 & 60.00 & 61.50 & 103.00 & 186.30 & 101.50 & 136.27 & 31.92 & 16.17 & 12.62 & 13.20 & 30.20 & 10.79 & 0.80 \\
\hline 28 & SC-28 & 60.00 & 62.00 & 99.50 & 198.40 & 114.40 & 116.98 & 30.30 & 15.48 & 13.57 & 14.40 & 32.00 & 7.49 & 0.77 \\
\hline 29 & SC-29 & 59.00 & 61.00 & 103.50 & 204.35 & 115.50 & 133.09 & 32.47 & 14.78 & 13.74 & 13.40 & 31.90 & 8.99 & 0.74 \\
\hline 30 & SC-30 & 59.00 & 61.00 & 104.00 & 197.50 & 114.00 & 170.41 & 30.53 & 15.27 & 13.17 & 13.00 & 33.40 & 7.64 & 0.75 \\
\hline 31 & SC-31 & 64.00 & 65.00 & 102.50 & 158.20 & 86.00 & 63.64 & 20.39 & 12.62 & 11.07 & 13.60 & 18.20 & 7.15 & 0.77 \\
\hline 32 & SC-32 & 58.50 & 60.00 & 103.00 & 177.00 & 98.70 & 110.47 & 29.45 & 15.40 & 13.11 & 13.80 & 32.80 & 10.15 & 0.78 \\
\hline 33 & SC-33 & 59.00 & 61.00 & 100.50 & 162.00 & 81.90 & 90.42 & 25.90 & 12.64 & 11.34 & 13.80 & 25.70 & 7.10 & 0.73 \\
\hline 34 & SC-34 & 62.50 & 64.00 & 105.00 & 151.30 & 86.00 & 70.12 & 25.53 & 11.57 & 10.96 & 13.80 & 23.00 & 7.64 & 0.78 \\
\hline 35 & SC-35 & 57.50 & 60.00 & 104.00 & 174.10 & 91.60 & 84.36 & 29.26 & 11.64 & 11.09 & 13.80 & 25.60 & 7.35 & 0.76 \\
\hline 36 & SC-36 & 56.50 & 59.00 & 103.50 & 187.80 & 107.50 & 148.78 & 31.30 & 16.13 & 13.67 & 13.80 & 35.00 & 8.33 & 0.79 \\
\hline 37 & SC-37 & 56.50 & 59.00 & 105.00 & 145.30 & 72.00 & 77.93 & 25.08 & 13.24 & 11.28 & 12.60 & 29.00 & 7.59 & 0.74 \\
\hline 38 & SC-38 & 58.50 & 59.50 & 97.50 & 187.10 & 112.10 & 96.15 & 29.33 & 14.53 & 13.64 & 14.00 & 29.20 & 7.20 & 0.75 \\
\hline 39 & SC-39 & 58.00 & 60.50 & 104.00 & 147.70 & 75.00 & 54.91 & 23.89 & 10.96 & 10.72 & 13.60 & 22.40 & 7.59 & 0.79 \\
\hline 40 & SC-40 & 57.50 & 59.50 & 101.50 & 153.40 & 80.10 & 84.72 & 27.69 & 13.70 & 13.13 & 14.60 & 28.00 & 8.48 & 0.71 \\
\hline 41 & SC-41 & 58.50 & 60.50 & 104.50 & 156.60 & 82.30 & 53.36 & 26.76 & 9.63 & 12.76 & 13.80 & 17.90 & 7.30 & 0.76 \\
\hline 42 & SC-42 & 57.50 & 61.00 & 100.50 & 185.30 & 108.50 & 101.97 & 30.63 & 13.16 & 13.27 & 14.40 & 25.95 & 7.60 & 0.75 \\
\hline 43 & HQPM $1 *$ & 59.00 & 61.00 & 103.00 & 194.70 & 94.20 & 91.06 & 26.79 & 13.89 & 12.11 & 12.40 & 32.50 & 8.63 & 0.67 \\
\hline 44 & Vivek QPM 9* & 51.00 & 53.00 & 92.50 & 206.40 & 98.00 & 123.68 & 29.67 & 15.95 & 14.04 & 16.40 & 35.80 & 8.58 & 0.81 \\
\hline \multirow[t]{2}{*}{45} & EHL161708** & 58.50 & 60.00 & 103.00 & 186.60 & 108.20 & 109.53 & 32.14 & 15.10 & 13.67 & 14.40 & 31.90 & 7.69 & 0.41 \\
\hline & Mean & 59.21 & 60.91 & 101.87 & 173.60 & 96.36 & 108.18 & 28.75 & 14.37 & 12.67 & 13.72 & 29.32 & 8.54 & 0.77 \\
\hline
\end{tabular}

* and ** indicates QPM and non-QPM checks, respectively 
Table.2 Estimates of mean, $\mathrm{SE}(\mathrm{m}), \mathrm{CV}, \mathrm{CD}$, range, heritability and genetic advance for various traits in QPM hybrids

\begin{tabular}{lllllccc}
\hline Traits & Mean \pm S.E(m) & CV $(\%)$ & CD @ (5\%) & Range & \multicolumn{2}{c}{$\begin{array}{c}\text { Heritability Genetic } \\
\mathbf{h}^{2} \text { bs }(\%)\end{array}$} & $\begin{array}{c}\text { Expected GA (as \%ance } \\
\text { of mean) }\end{array}$ \\
\hline Days to 50\% pollen shed $59.21 \pm 0.60$ & 1.44 & 1.72 & $51.00-65.50$ & 89.70 & 4.89 & 8.26 \\
Days to 50\% silking & $60.91 \pm 0.68$ & 1.57 & 1.93 & $53.00-66.50$ & 84.50 & 4.23 & 6.94 \\
Days to 75\% maturity & $101.87 \pm 0.73$ & 1.01 & 2.07 & $92.50-105.50$ & 84.50 & 4.54 & 4.45 \\
Plant height (cm) & $173.60 \pm 3.02$ & 2.46 & 8.61 & $133.50-211.00$ & 96.00 & 42.25 & 24.34 \\
Cob placement height & $96.36 \pm 3.49$ & 5.12 & 9.93 & $65.30-120.00$ & 88.10 & 25.96 & 26.94 \\
(cm) & & & & & & & \\
Grain yield/plant (g) & $108.18 \pm 4.27$ & 5.58 & 12.17 & $49.63-170.66$ & 96.70 & 66.00 & 61.01 \\
100-seed weight (g) & $28.75 \pm 1.26$ & 6.20 & 3.59 & $18.54-34.06$ & 78.20 & 6.14 & 21.35 \\
Cob length (cm) & $14.37 \pm 0.83$ & 8.14 & 2.36 & $9.63-17.38$ & 56.10 & 2.04 & 14.19 \\
Cob girth (cm) & $12.67 \pm 0.63$ & 7.05 & 1.80 & $10.57-14.31$ & 47.60 & 1.21 & 9.55 \\
Kernel rows/ear & $13.72 \pm 0.49$ & 5.05 & 1.40 & $12.40-16.40$ & 26.20 & 0.44 & 3.17 \\
Grains/row & $29.32 \pm 1.43$ & 6.88 & 4.07 & $17.90-36.60$ & 82.10 & 8.06 & 27.47 \\
Protein content (\%) & $8.54 \pm 0.26$ & 4.34 & 0.75 & $7.10-10.94$ & 89.70 & 2.13 & 24.99 \\
Tryptophan content (\%) & $0.77 \pm .001$ & 2.32 & 0.04 & $0.41-0.87$ & 93.90 & 0.14 & 18.23 \\
\hline
\end{tabular}


Present findings are in consonance with those previously reported by Singhal et al., (2006), Mahan (2012), Tusuz and Balabanli (1997), Bekele and Rao (2014), Muchie and Fentie (2016) and Poudel and Poudel (2016). The traits which exhibited high heritability revealed lesser influence of the environment and greater role of genetic component of variation. Therefore, selection for these traits on the basis of phenotypic expression would be more effective for indirect improvement of yield. However, the selection for improvement of such characters may not be useful, because broad sense heritability is based on total genetic variance which includes additive, dominant and epistatic variances. Thus, estimates of heritability are more advantageous when expressed in terms of genetic advance as a per cent of mean.

The character grain yield per plant $(61.06 \%)$ recorded high magnitude of genetic advance as percentage of mean. However, it was moderate for cob placement height $(26.94 \%)$ and grains per row (27.47\%) which are in congruence with the findings of Bekele and Rao (2014), Muchie and Fentie (2016) and Poudel and Poudel (2016). The estimates of heritability and genetic advance are two complementary concepts (Hanson, 1963). For predicting reliable estimates of additive and non-additive effects, heritability should be considered in conjugation with genetic advance (Burton, 1952; Johnson et al., 1955). On this consideration high heritability coupled with high genetic advance as a per cent of mean was observed for grain yield per plant indicated predominance of additive gene action and selection may be effective for this trait. Similar results were reported by Kanagarasu et al., (2013) and Reddy et al., (2013). High heritability coupled with moderate genetic advance as percentage of mean was observed for cob placement height and grains per row, indicating predominance of additive and non-additive gene action in the expression of this trait therefore, this character can be improved by careful and restricted selection. These findings are in congruence with Prakash et al., (2006) and Lal and Singh (2014). Low estimates of heritability and genetic advance as a per cent of mean indicates that inheritance is being influenced by inter-allelic interaction rather than intra-allelic interaction.

Overall, it can be concluded that $\mathrm{F}_{1}$ hybrids viz., SC-8, SC-20, SC-21 and SC-27 were observed best for yield and its component traits. The QPM $F_{1}$ hybrid SC-13 was found superior for tryptophan and protein content. The present study illustrated the existence of wide ranges of variations for most of the traits among the QPM $F_{1}$ hybrids, which provides opportunities for genetic gain through selection. The estimates of heritability coupled with genetic advance as per cent of mean was high for grain yield per plant followed by cob placement height and grains per row. Thus, these plant traits deserve greater attention for developing high yielding QPM hybrids.

\section{Acknowledgement}

Researchers are thankful to CSK Himachal Pradesh Agricultural University, Palampur for their technical and financial assistance.

\section{References}

Anonymous. 2012. The State of Food Insecurity in the World 2012. Strengthening the enabling environment for food security and nutrition. Food and Agriculture Organization, Rome.

Anonymous. 2014. The State of Food Insecurity in the World 2014. Strengthening the enabling environment for food security and nutrition. Food and Agriculture Organization, Rome.

Anonymous. 2015a. Annual Progress Report 
Rabi Maize 2014. All India Coordinated Research Project on Maize. Indian Institute of Maize Research, New Delhi, India.

Anonymous. 2015b. World agricultural production. Foreign Agricultural Service, USDA.

AOAC. 1965. Official methods of analysis of the association of official agricultural chemists, Washington DC, pp. 744-745.

FAO. 1992. Maize in human nutrition, Rome, Italy.

Bekele, A. and Rao, T.N. 2014. Estimates of heritability, genetic advance and correlation study for yield and it's attributes in maize (Zea mays L.). J. Plant Sci., 2: 1-4.

Bilgin, O., Korkut, K.Z., Baser I., Dalioglu, O., Ozturk, I., Kahraman, T. and Balkan A. 2010. Variation and heritability for some semolina characteristics and grain yield and their relations in durum Wheat (Triticum durum Desf.). World J. Agric. Sci., 6: 301-308.

Burton, G.W. 1952. Quantitative inheritance in grasses, Proceedings of 6th International Grassland Congress, 1: 277-283.

Hanson, W.D. 1963. Heritability. In: Statistical Genetics and Plant Breeding (Eds.) W.D. Hanson, and H.R. Robinson. National Academy of Science, Washington DC, USA, Pp. 125-140.

Johnson, H.W., Robinson, H.F. and Comstock, R.E. 1955. Estimates of genetic and environmental variability in soybeans. Agron. J., 47: 314-318.

Kanagarasu, S., Nallathambi, G., Ganesan, K.N. and Kannan, S. 2013. Genetic variability and association analysis for yield and its components in single cross hybrids of maize (Zea mays L.). Electron. J. Plant Breed., 4: 1319-1324.

Lal, M. and Singh, D. 2014. Studies of variability using morphological and quality traits in quality protein maize (Zea mays L.). Electron. J. Plant Breed., 5: 526-530.

Lush, J.L. 1940. Intra-sire correlation and regression of offspring on dams as a method of estimating heritability of characters. Proc. Amer. Soc. Anim. Prod., 33: 293-301.

Mahan, A.D. 2012. Genetic combining analysis of food-grade maize: colored and quality protein. M.Sc. Thesis, Department of Soil and Crop Sciences, Texas A\&M University.

Mertz, E.T., Bunathan, J.R. and Misra, P.S. 1975. In Protein Quality, Agric Experiment Stn. Bull No. 70 Purdue University, USA: 11.

Muchie, A. and Fentie, D. 2016. Performance evaluation of maize hybrids (Zea mays L.) in bahir dar zuria district, North Western Ethiopia. J. Agric. and Soil Sci., 4(3): 37-43.

Osborne, T.B. and Mendel, L.B. 1914. Nutritive properties of the proteins of the maize kernel. J. Biol. Chem., 18: 116.

Prakash, O., Shanthi, P., Satyanarayana, E. and Saikumar, R. 2006. Studies on genetic variability exploitation for quality traits and agronomic characters on quality protein maize (QPM) germplasm (Zea mays L.). Ann. Agric. Res., 27: 147-153.

Prasanna, B.M., Vasal, S.K., Kassahun, B. and Singh, N.N. 2001. Quality protein maize. Curr. Sci., 81(10): 1308-1319.

Poudel, M.R. and Poudel, H.K. 2016. Genetic variability, heritability and genetic advance of yield attributing traits in winter maize. Int. J. Grad. Res. Rev., 2(1): 9-12.

Reddy, V.R., Jabeen, F., Sudarshan, M.R. and Rao, A.S. 2013. Studies on genetic variability, heritability, correlation and path analysis in maize (Zea mays L.) over locations. Int. J. Appl. Biol. Pharm. 
Technol., 5: 195-199.

Singhal, N., Verma, S.S., Baskheti, D.C. and Kumar, A. 2006. Heritability, genetic advance, correlation and pathcoefficient estimation in high quality protein maize (Zea mays L.). Asian J. Bio Sci., 1(2): 54-56.

Singh, N., Rajendran, R.A., Shekhar, M., Jat, S.L., Kumar R. and Kumar, R.S. 2012. Rabi Maize Opportunities Challenges, Directorate of Maize Research, Pusa Campus, New Delhi -110 012, Technical Bull., 9: 32.
Tusuz, M.A. and Balabanli, C. 1997. Heritability of main characters affecting yield of some maize varieties and determination of relationships among these characters. Anadolu, 7(1): 123134.

Upadhyay, S.R., Gurung, D.B., Paudel, D.C., Koirala, K.B., Sam, S.N., Prasad, R.C., Pokhrel, B.B. and Dhakal, R. 2009. Evaluation of Quality Protein Maize (QPM) genotypes under rainfed mid hill environments of Nepal. Nepal J. Sci. and Technol., 10: 9-14.

\section{How to cite this article:}

Jay Prakash, S. Lata, Ankita Sharma, R.D. Vekariya, J.K. Sharma and Ankita Sood. 2017. Evaluation of Quality Protein Maize (Zea mays L.) Hybrids for Quantitative and Quality Traits. Int.J.Curr.Microbiol.App.Sci. 6(4): 1851-1859. doi: https://doi.org/10.20546/ijcmas.2017.604.220 